\title{
An Analysis of Primary School-Aged Children's Drawings and Their Play Area Preferences
}

\author{
Gökçen Firdevs Yücel Caymaz, Hilal Türkdoğdu \\ Istanbul Aydin University, Istanbul, Turkey \\ Erincik Edgü \\ Istanbul Commerce University, Istanbul, Turkey \\ Nursena Karaş \\ Istanbul Aydin University, Istanbul, Turkey
}

\begin{abstract}
The aim of this study was to study the expectations of children in the 8-10 age group regarding their play areas, and to generate planning and design data for these areas accordingly. For the study, which used cognitive mapping procedures, 176 children studying in the third and fourth years of a primary institution in Istanbul were asked to draw their fantasy children's play areas. In the analysis of their drawings, the children's preferences were identified in three main categories: the natural environment, the built environment, and human features. At the end of the evaluation, it was determined that there was a higher preference among the children for elements of the built environment, relative to the natural environment.
\end{abstract}

Keywords: children's drawings, children's perceptions, play areas, play elements

\section{Introduction}

In environments where children have physical experiences, play areas have an important role in their growth and development; in urban spaces, these areas have a significant impact on children's physical, social, and emotional development (Hart, 2002; Solomon, 2005; Tovey, 2007; Schirrmacher, 2002). External spaces provide opportunities for studying children's environments, their acquisition of self-confidence, and their muscular development and coordination (Little \& Wyver, 2008). Play areas in open spaces where there is interaction with water and the earth provide pleasurable choices for children, as well as opportunities for them to find and create places where they can play on their own; in these spaces, they can collect different objects and develop their hobbies (Clements, 2004).

In conceptualizing their experience, it is important to understand their spatial perceptions and how they process knowledge. Although in certain cases, perception and data processing may overlap, perception is defined as the way we take information into our brain through the awareness of our sensations; whereas data processing

Gökçen Firdevs Yücel Caymaz (corresponding author), Dr., Department of Industrial Products Design, Istanbul Aydin University.

Hilal Türkdoğdu, Ph.D. candidate, research assistant, Department of Urban Design and Landscape Architecture, Istanbul Aydin University.

Erincik Edgü, Ph.D., associate professor, Department of Interior Architecture and Environmental Design, Istanbul Commerce University.

Nursena Karaş, Interior Architect candidate, Istanbul Aydin University. 
also involves, thinking, problem-solving, and integrating the information with ideas (Canter, 1977); in addition to perceptual processing, it includes thinking, problem-solving, and organizing knowledge and ideas (Downs \& Stea, 1973). The theories that play an important role in environmental perceptions have to be integrated with perceptions of movement, spatial perceptions, and the organization of sensory data (Lang, 1987); and regardless of how past experiences provide a basis for understanding new ones (Lang, 1987), this mainly depends on children's imagination and activities (Tuan, 1977).

External environments contribute significantly to children's cognitive and behavioral development. According to Moore and Wong (1997), compared to closed areas, the ways external spatial environments contribute to active learning stimulate children's development in every way. Pyle (2002) argued that what is provided by natural environments augments cognitive development by helping to develop children's awareness, observational abilities, and reasoning capacity. Fishman (2001) suggested that they affect children's cognitive development because they offer possibilities for exploration, experimentation, and play. Because children interact directly with their surroundings, they perceive and experience natural and built environments differently from the way adults do: Young children have more positive reactions to external spaces; and adults generally see nature as the background to their activities, while children see nature as a stimulus to their activities and as a constituent component of their experience (White \& Stoecklin, 1998).

\section{Literature Review}

A child's perceptions are formed, according to the data, it receives from its surroundings; and children perceive their surroundings by living in them directly and also as they are mediated by spatial representations, such as those provided by written or oral definitions, or models and maps (Blades, 1989). Research shows that for many children, expressing themselves through drawing is easier and more enjoyable than responding to questions (Chang, 2005). Drawings are reflections of mental images; and through them, children can more comfortably convey the ideas in their mental world about their environment - their perceptions, knowledge, interest, and experiences (Barraza, 1999; Brooks, 2009; Crook, 1985; Lewis \& Greene, 1983; Matthews, 1985; Malchiodi, 1998; Schirrmacher, 2002; Van-Summers, 1984). As reflections of their observations, experiences, problems and ideas, children's drawings are a valuable source for understanding how they think: there are correlations between their drawings and their intellectual development (Luquet, 1913; Piaget, 1969); and according to Piaget (1955), if children cannot form mental images related to space, they cannot be expected to draw properly (Yavuzer, 1992).

Studies done on children's spatial perceptions, and particularly, Piaget's theories have laid a foundation for research in the field of environmental and spatial data processing. In Luquet's five-stage grouping of children's drawings, one of the stages of development is when children are at the age of eight and above years: At this stage, with a certain point of view, they begin to use proportions and construct relations between objects (Luquet, 1913). And in Lowenfeld and Brittain's six-phase classification of development, children's drawings in the 9-12 age group are schematically characterized as containing independent and more realistic elements (Lowenfeld \& Brittain, 1987). Piaget (1955), interested in the ways children react to their environment, considered this interaction as a part of the cognitive learning process and defined the 7-12 age group as the period when concrete operations are developed. At this stage, a large proportion of children have a tendency to not pay attention to the details of objects and instead, to generally connect together perceptions and unrelated objects in unified concepts (syncretism). The child becomes aware for the first time that objects and spaces are related in ways that are independent of him/her, and moves away from being self-centered (Altman \& Chemers, 1980). 
The systematic measuring of children's drawings begun by Appel in 1931 and Wolff in 1942 is still developing today in research on models of children's perceptions and behaviors within different environments. Koppitz (1968) classified children's drawings according to the appearance in them of animals, flowers, houses, cars, boats, and planes; Van-Summers (1984) classified them in terms of animals, flowers, water, mountains, sun, and trees. Robin Moore asked boys and girls in the 9-11 age group to draw their favorite places; in the resulting drawings, while play areas came second as the most preferred places, in play areas as a whole, very specific playground equipment was referred to most frequently (Provenzo, 1993). According to Robinson (1995), reading and activities in play areas were the most popular subjects in children's drawings. Strommen (1995) asked 40 first-year students to draw forests with living animals in them, and in this research, the drawings of living things (plants, mammals, birds, and fish) were grouped according to their relationships with other living or non-living things. Aura, Horelli, and Korpela (1997) created a classification of nature, the built environment, and physical human existence within environments, as they were depicted in the drawings. Barraza (1999) spoke with 741 students in the 7-9 age group from nine schools and asked them to draw their perceptions of the environment, their important expectations about the future, and the things that concerned them; the resulting drawings were grouped according to their focus on water, animals, plants, human beings, and houses. Omet and al-Asad (2002) asked children in the 9-12 age group to express what kinds of play environments they would like to have; and the resulting drawings were classified according to their focus on natural forms (trees, flowers, birds, mountains, hills, ponds, and grass) and man-made structures (objects for playing with, structures for playing in or on, walls, buildings, walking paths, and canopies or shaded areas). According to a study of children's drawings done in 2004 by Erdoğan, Haktanir, Köksal Akyol, and Çakir-İlhan, children preferred natural and outdoor environments to play in, and what they were thinking of was simple play equipment, such as, in order of preference, swings, slides, balls, jumpropes, toy cars, balloons, and seesaws (Erdoğan et al., 2004).

Cronin-Jones (2005) evaluated drawings by 77 children in the 6-12 age group from seven schools, and found that the boys preferred structural elements, like seating facilities, while the girls showed a preference for for natural elements like butterfly gardens, sitting spaces, flower gardens, and ponds. Tamoutsei and Polyzou (2010) asked 187 children in the 6-12 age group to draw their ideal school garden, and classified the drawings in three groups, according to the preferences they showed for: (1) the natural environment: ground cover, plants, animals, water, and sky; (2) the built environment: play areas, other constructed visual elements, sports fields; and (3) built environmental elements resembling nature: according to the proportions of plant cover and covered space. Yeager (2012) asked 30 children in the 7-8, 10-12, and 12-13 age groups to draw their favorite places in the neighborhood, and a place outside they had never been to before: The drawings were classified in one of three groups, according to whether they showed natural elements (trees, grass, sky, sun, flowers, and rocks), elements of the built environment (buildings, pavements, lighting poles, streets, and cars), or aspects of play (parks, play spaces, types of games, and recreational elements). Panula's (2012) study concluded that there was a majority preference for built and social environments where water and garden elements were featured. When Sali, Köksal Akyol, and Baran (2014) asked 182 children at the preschool and primary-school level from seven different schools to draw the play areas in their schools' surroundings and their ideal play spaces, they found that the children drew fixed and moving play equipment, plants, animals, human forms, and imaginary elements. In a research study by Dikmen, all the children's drawings showed elements of outside space, such as the sun, clouds, fireworks, and green areas; this was taken as an indication of children's desires to play games 
in outdoor spaces. Again, colorful play areas and smiling children were depicted in nearly all the drawings; and this result was taken to indicate that the children saw their play areas as places that gave them pleasure and made them feel happy (Dikmen, 2015). And a study by Yilmaz, Düzenli, and Özkan (2017) asked 210 children in the 6-7 age group to draw their ideal school garden: the drawings were classified according to whether they showed natural components, such as trees, flowers, water, sky, rocks, animals, sand, or earth boxes; or artificial components, such as swings, skateboard parks, toys, balls, bicycles, climbing frames, sitting areas, or flagpoles (Yilmaz et al., 2017).

\section{Objective and Methods}

\section{Objective}

The aim of this study was to obtain preliminary data regarding the criteria that may affect effective planning and design of children's play areas in open spaces. The research literature shows that awareness of spatial perception is at a suffiicient level in children in the 8-10 age group. Today in the Turkish population, such influences as the media and peer pressure have created a demand for consumer goods, and as a result, children's use of technological tools is increasing. For this reason, it is inevitable that the expectations of children living in metropolises in our day will be different from those that appear in data obtained from studies done during times when technology was not in such prevalent use. In this study, the aim was to classify the drawings made by students in this age group in terms of play areas, what play elements they desired within these areas, and the elements of the natural and built environment which could affect their perceptions of a play space. For this purpose, hypothesis $\mathrm{H} 1$ was generated, and then tested to see if it was valid.

In choosing this focus area, more than the thoughts of the children from different socio-demographic groups, the aim was to determine the preferences of the 8-10 age group in general. This age group was prioritized, because it is the period when children's awareness of the possibility of finding relationships between objects and spaces, and the development of environmental awareness, are just beginning; so that the main determining factor is that the children's drawings are independent, and they are able to transform more real elements into schematic expressions.

$\mathrm{H}$ 1: Children show much greater preference for elements of the natural environment than for those of the built environment in their play areas.

\section{Sample Area}

This research began with a pilot study of 15 individuals conducted in December 2016 in Beylikdüzü, a middle-income neighborhood of Istanbul. In December 2017, the data provided by 161 student drawings was analyzed. The necessary permissions for the study were received from the provincial and state National Education Directorates; and in consultation with the school principals, class teachers, and student counselors, lists of third- and fourth-year students were obtained. Five groups of each of the two classes, making ten groups in total, were consulted.

\section{Methods Used}

The substance of the study was explained to students participating in the classes, and they were told that what was wanted was for them to draw their ideal children's play areas. All the students were not required to participate in the study: 100 of the 120 in the third-year, and 61 of the 128 in the fourth-year participated. The students were given 80 minutes to complete their drawings, and were asked to write their names and surnames, ages, and class 
years, as well as the story behind it, on the back of their drawing.

Sensory perceptions of the environment and space at the end of a period of cognitive processing could be explained as cognitive mapping of information and transformation of comprehension. In other words, the concept of cognitive mapping, understood as a kind of modeling or representation of the physical environment, can also be expressed as a set of acquired replications of perceptions recalled from memory and assembled in the mind (Downs \& Stea, 1973; Jacobson, 1998). The study made use of the procedures for cognitive mapping employed in numerous other similar studies.

In preliminary testing before the main study was conducted, the children were asked to explain their drawings verbally, and with this knowledge, the elements which could be used in the data analysis were determined, and the task of classification undertaken. Following the preliminary testing, it was decided that for the main study, in order to increase the scope of the sample, the stories behind the drawings would be asked for in writing (see Table 1), standard-sized paper would be used, children would write their names on their drawings, and they would be free to choose the medium they preferred (dry paint, pastel, watercolor, etc.).

Table 1

An Example of Preliminary Data Classification (Prepared by Authors)

\begin{tabular}{|c|c|c|c|c|c|c|c|}
\hline \multirow[b]{2}{*}{ A student's drawing } & \multirow{2}{*}{$\begin{array}{l}\text { Elements of the } \\
\text { drawing } \\
\text { (number of } \\
\text { repetitions) }\end{array}$} & \multirow[b]{2}{*}{$\begin{array}{l}\text { Natural } \\
\text { environment }\end{array}$} & \multicolumn{3}{|c|}{ Built environment } & \multirow[b]{2}{*}{$\begin{array}{l}\text { Human } \\
\text { figures }\end{array}$} & \multirow[b]{2}{*}{ The story behind the drawing } \\
\hline & & & $\begin{array}{l}\text { Play } \\
\text { elements }\end{array}$ & $\begin{array}{l}\text { Park } \\
\text { furnishings }\end{array}$ & Other & & \\
\hline 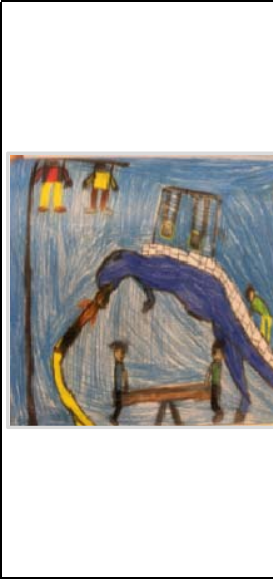 & $\begin{array}{l}\text { Sun-1 } \\
\text { Plant image-1 } \\
\text { Climbing play } \\
\text { element-1 } \\
\text { Swings-2 } \\
\text { Slide-1 } \\
\text { Seesaw-1 } \\
\text { Treehouse-1 } \\
\text { Image of a } \\
\text { child-5 }\end{array}$ & 2 & 5 & 1 & 0 & 5 & $\begin{array}{l}\text { The individual who made the } \\
\text { drawing knew the park as } \\
\text { "Adventure Park." Everything } \\
\text { depicted in the park shows } \\
\text { action. On the top left of the } \\
\text { drawing is a very high swing, } \\
\text { and you get to the swing by } \\
\text { going up a ladder Climbing a } \\
\text { dinosaur's tail, you come out } \\
\text { through its mouth, which is } \\
\text { blowing out fire, down onto the } \\
\text { slide. Above the dinosaur are the } \\
\text { swings; just below it is a seesaw } \\
\text { And to the right, again from the } \\
\text { dinosaur's tail, you climb up a } \\
\text { tree to a playhouse at the top. }\end{array}$ \\
\hline
\end{tabular}

In classifying children's drawings, it is important to identify the natural facilities and built equipment in the play areas correctly. A child's play areas are constituted by both natural and built surroundings. The elements of natural surroundings include, in addition to botanical elements of the landscape, such as grass, trees, bushes, ground cover and flowers, and elements like the sky, the sun, and clouds. The built elements include, besides play equipment intended to satisfy their need to play, park facilities, buildings, and sports fields. Among the play elements that may be found in play areas are frames and equipment for balancing, climbing, jumping, vaulting, and turning or spinning, elements designed to stimulate the imagination, closed structures, swinging or rocking equipment, and such things as slides and seesaws (see Figure 1). Besides these, play areas may also include water features, hillocks for playing around, tunnels, statues, large wooden blocks, and other objects made from recycled materials (Altman \& Zube, 2012; Collins, 2008; Bechtel, 1997; Cohen, 1985; Eriksen, 1985; Sluss, 2014; Scarlett, 2005; Fromberg \& Bergen, 1998; Forsyth, Musacchio, \& Fitzgerald, 2005; Provenzo, 1993). 
The drawings were classified according to: (1) natural surroundings, (2) built environment, and (3) human features; and the number of repetitions and frequency percentages for each element were calculated to test the hypothesis (see Figure 2).
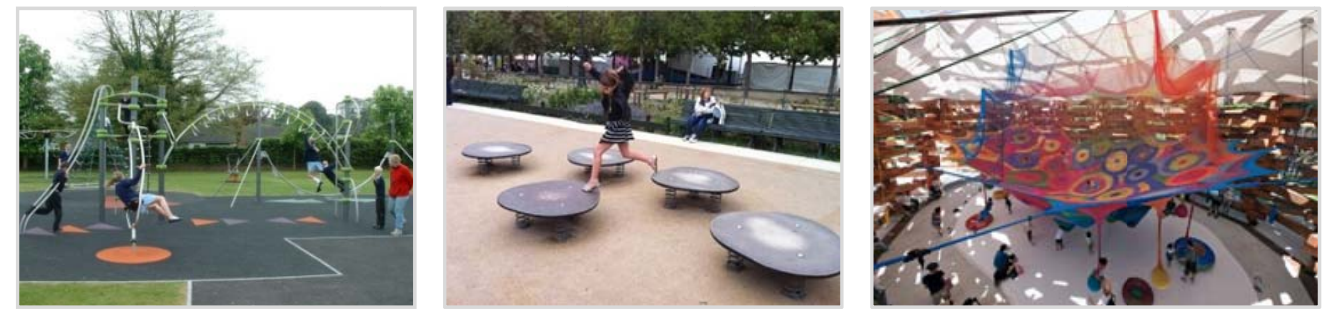

Figure 1. Climbing frames, jumping surfaces, suspended play surface (Source: URL 1, 2, \& 3).

URL 1. https://s-media-cache-ak0.pinimg.com/originals/4c/bc/bf/4cbcbf3982206a58cac5d5aa7c808118.jpg. URL 2. https://www.pinterest.co.uk/pin/431501208019692359/.

URL 3. https://tr.pinterest.com/pin/119908408805963473/.

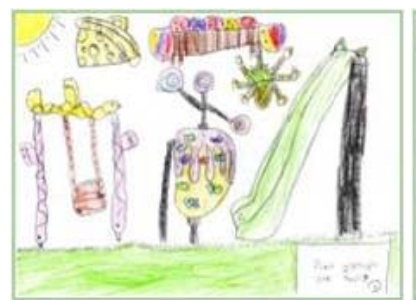

\section{Analysis of the Data}

At the stage of data analysis, the children's drawings, bearing in mind the stories behind them, were evaluated in three main groups: natural surroundings, built environment, and human features. From the results of the evaluation of the children's drawings, it was determined that in the majority, the built environment was prioritized over natural surroundings, and in addition, that there was a rather high proportion of human figures in the drawings. There were also a few images in the drawings which could not be identified (see Figures 3 and 4).

Most of the drawings that prioritized the built environment focused on the play elements first and the park facilities second (see Figures 5 and 6); most of those that prioritized the park facilities focused on water features, seating, and trash cans (see Figures 7 and 8); most of those that prioritized play elements focused on swings and slides (see Figures 9 and 10). And most of those that prioritized the natural environment focused on images of clouds, animals and human figures (see Figures 11 and 12).

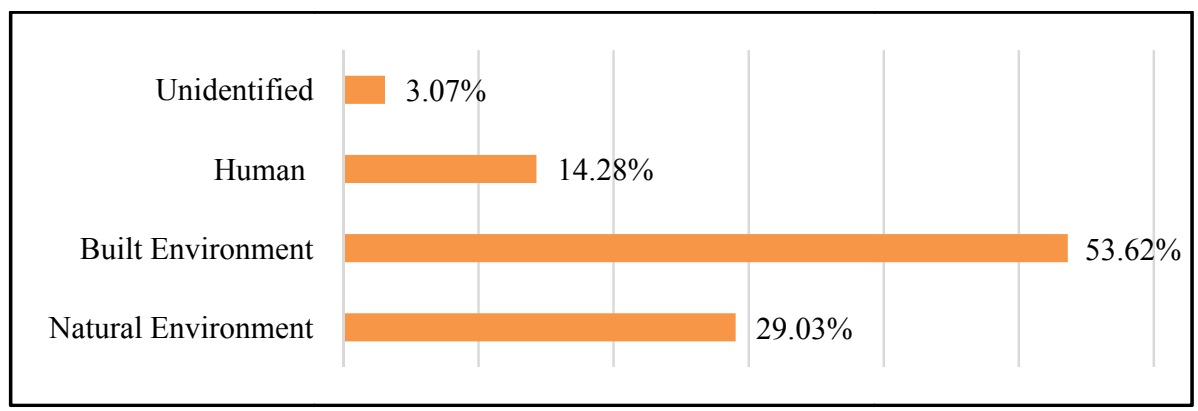

Figure 3. General evaluation of drawings. 

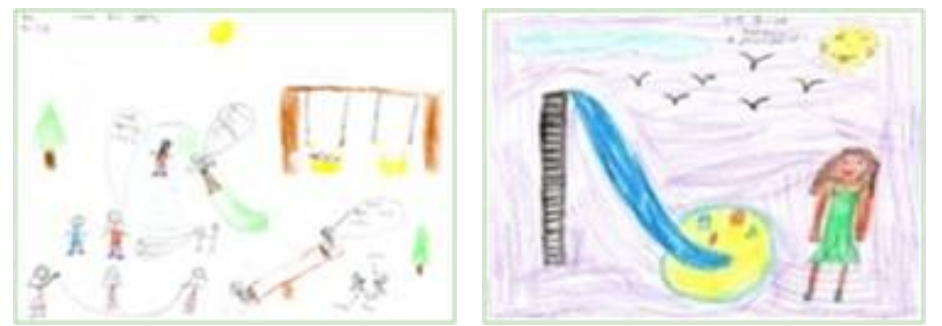

Figure 4. Drawings with human figures included.

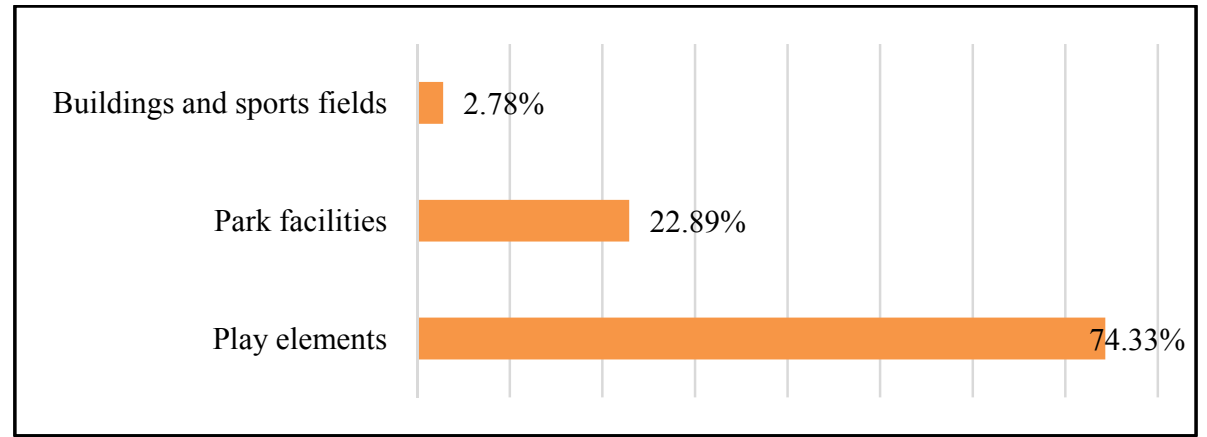

Figure 5. Evaluation of the built environment through drawings.

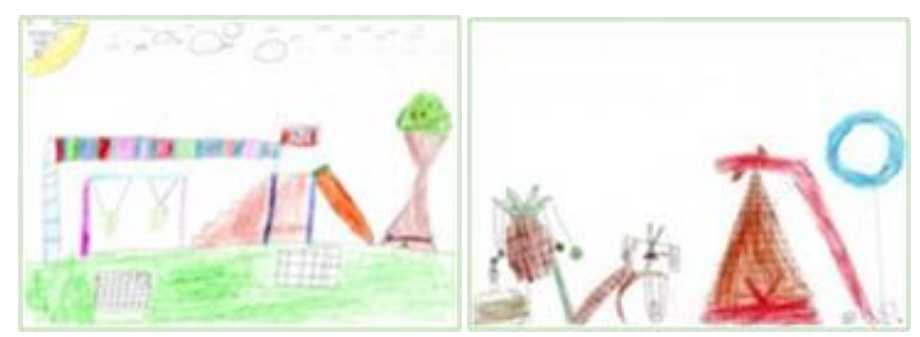

Figure 6. Drawings of buildings and a sports field.

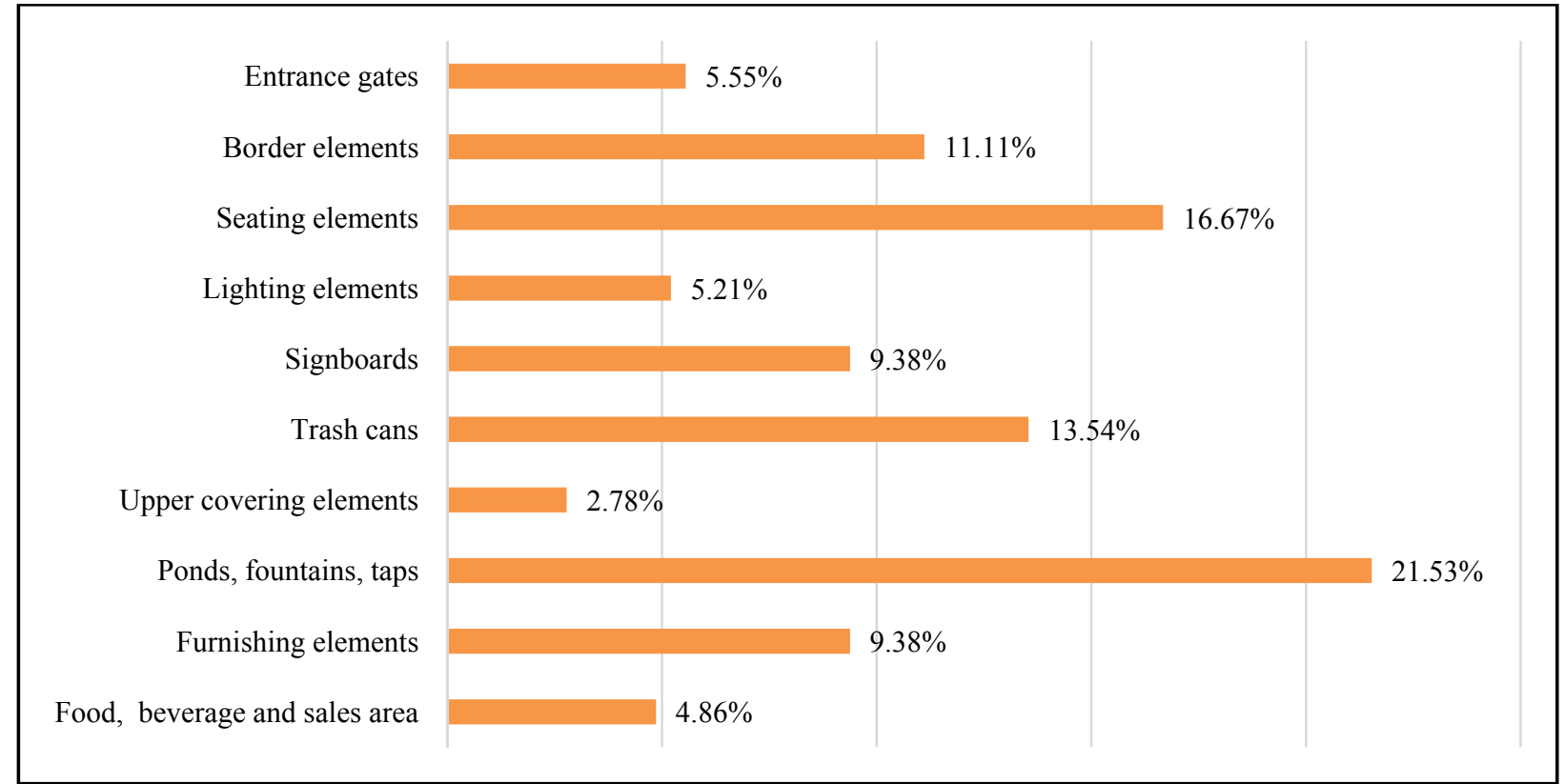

Figure 7. Evaluation of preferences for park facilities in the built environment. 

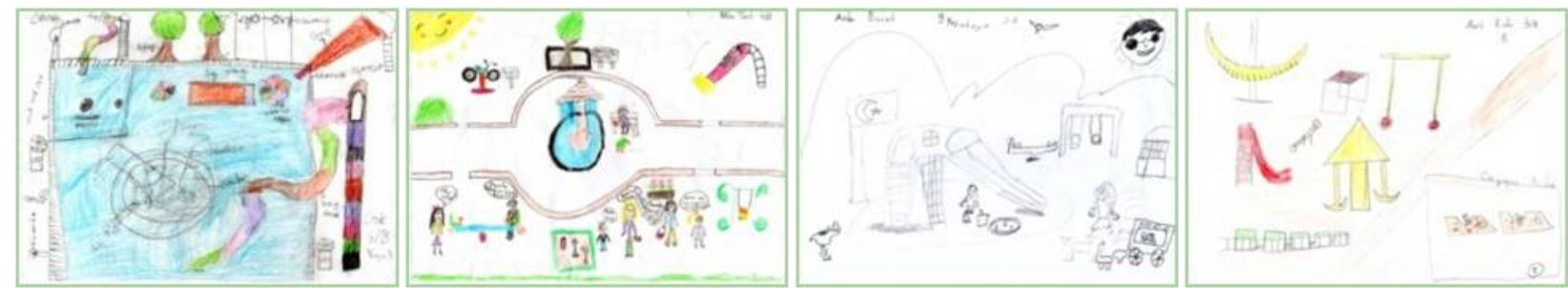

Figure 8. Drawings of park facilities.

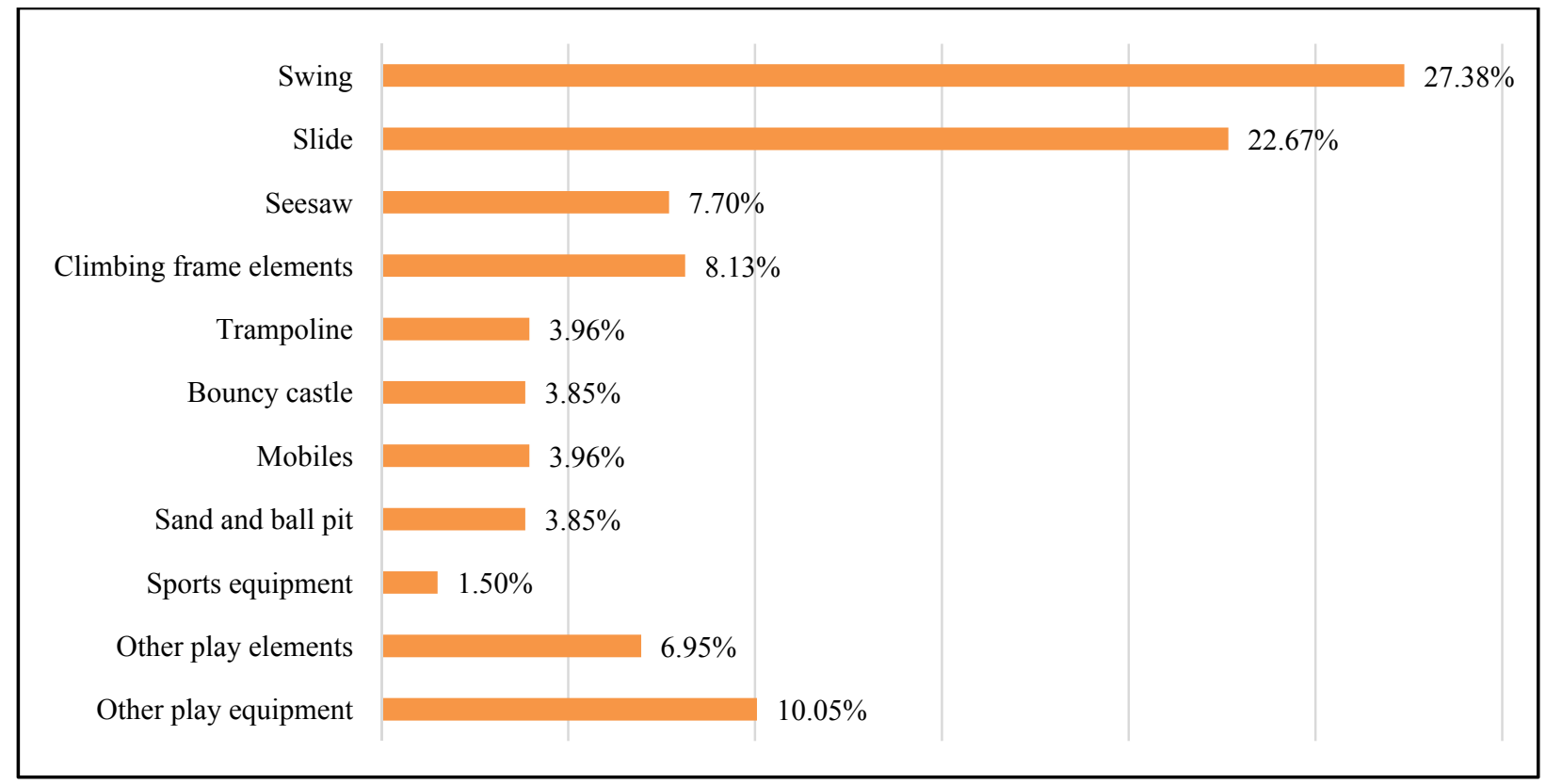

Figure 9. Evaluation of preferences for play elements in the built environment.
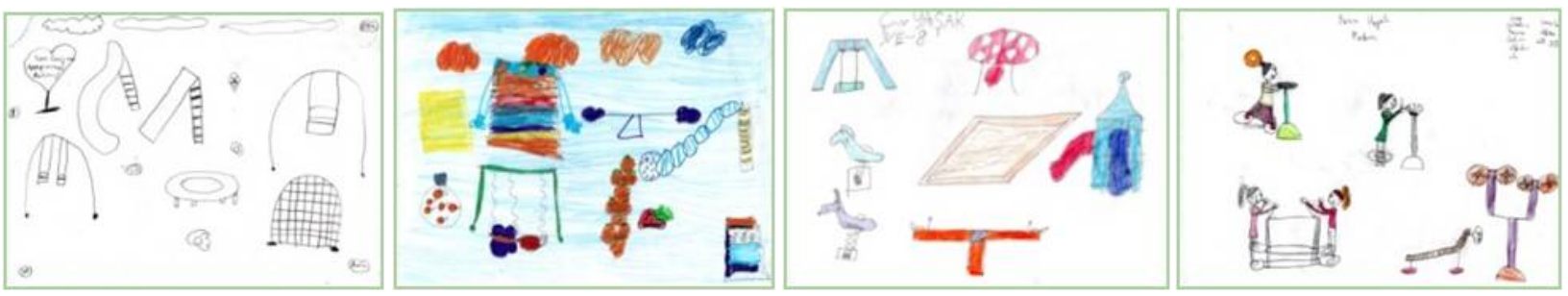

Figure 10. Drawings of play elements.

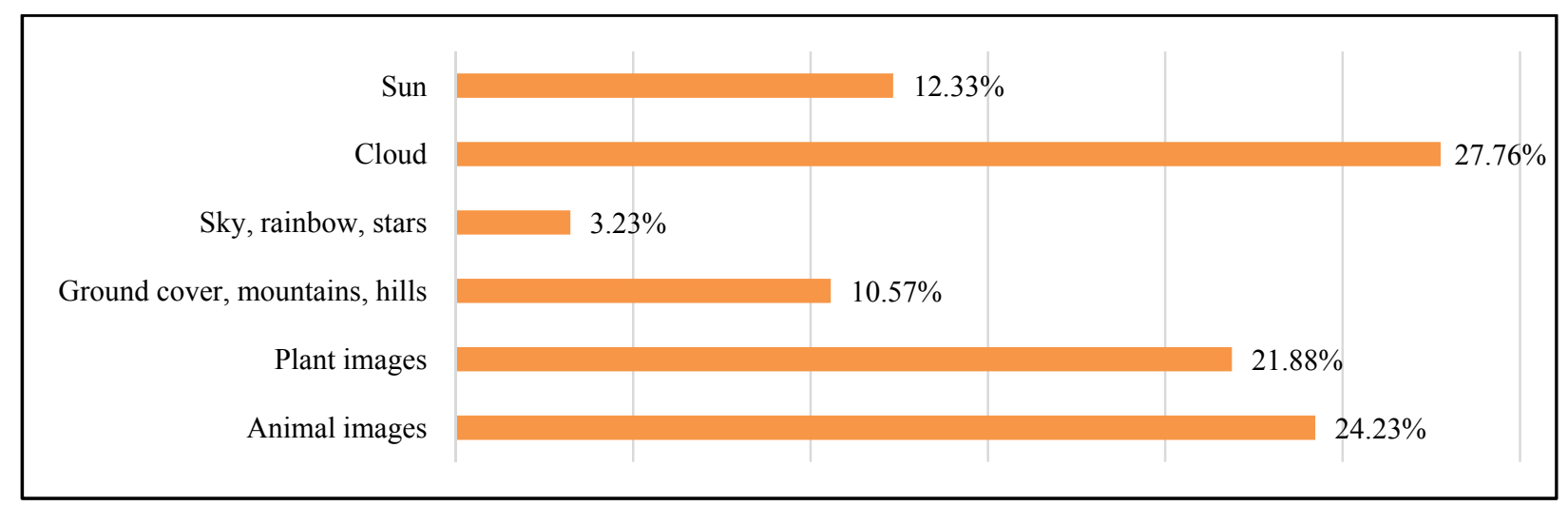

Figure 11. Evaluation of preferences in the natural environment. 


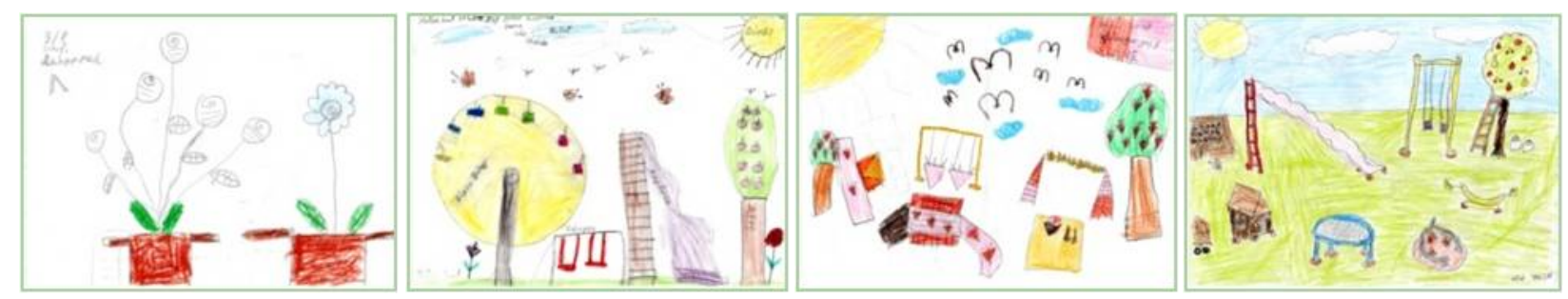

Figure 12. Children's drawings related to the natural environment.

At the stage of data analysis, the children's drawings, together with the stories behind them, were evaluated in three main groups: natural environment, built environment, and human features. The $\mathrm{H} 1$ hypothesis was analyzed using Excel software; and it was found that it was not confirmed.

When the hypothesis H 1 was tested (Children show much greater preference for elements of the natural environment than for those of the structural environment in their play areas), it was seen (see Figures 3 and 4) that a majority of the children drew elements of the built environment (64.9\%), compared to the number who focused on natural environment (35.1\%).

Both the proportion of girls who depicted elements of the natural environment and of those who depicted the built environment was greater than those of the boys: Thirty-six point four percent of the girls preferred the natural environment and $63.6 \%$ the built environment, while the respective proportions of the boys were $33.5 \%$ and $66.5 \%$. When the two groups were compared, it was seen that the proportion of human figures in the boys' drawings was greater $(62.1 \%)$, a significant difference.

Within the built environment, $42.1 \%$ of the boys preferred play elements, compared to $57.9 \%$ of the girls; $51 \%$ of the boys and $49 \%$ of the girls showed a preference for street furniture. The closeness of these results suggests that there is no significant correlation between gender and preferences for play elements or street furnishings. Again, boys showed a greater preference (68.6\%) for structures and sports fields within other elements of the built environment than girls did; and the preference of boys for sports areas was an expected result. It was observed that boys depicted considerably more unidentifiable elements in their drawings $(77.8 \%)$.

Among the elements of street furnishings, boys drew more water elements (24.5\%), seating elenets (13.6\%), and trash cans $(12.2 \%)$; and girls drew more seating elements $(19.9 \%)$, water elements $(18.4 \%)$, and trash cans $(14.9 \%)$ than other elements. It was observed that the boys drew lighting (86.7\%) and water elements (58\%) proportionately more than the girls; and girls drew refreshment and sales facilities (71.4\%) proportionately more than the boys.

Both the boys and the girls drew many more images of swings (27.4\%) and slides (22.7\%) than of other play elements. Girls drew a greater proportion than the boys did of swings $(61.3 \%)$, other play equipment (69.1\%) and slides (55.7\%).

All the forms depicted within the natural environment by the girls were more numerous in proportion to those drawn by boys. Among these, the most frequently ocurring were the sky $(72.7 \%)$, plant forms $(61.1 \%)$, and ground cover $(66.7 \%)$.

\section{Conclusion}

The main aim of this study was to make use of the results obtained to develop their implications with a view to increasing the comfort and quality of the environments used by children. 
Today, parks, children's play areas, and the colorfully equipped play areas in urban shopping centers, which are created with security concerns in mind, are produced more as locations for children to spend time in, than as spaces designed to stimulate their creative powers.

Van Eyck (1959) commented that play areas are not about objects but for children to move about in, thought that stepping stones, climbing frames, vaulting tubes, and sandboxes would suffice for the purpose; these objects could just as well become, in children's imagination, an Eskimo's igloo or a pirate ship. In fact, in our day, if so desired, a complete children's play area could be set up in the form of a pirate ship made of plastic. Kanıpak, writing in 2014, contended that slides in the shape of bananas and seesaws shaped like frogs do not provide suitable opportunities for children to play, and he argued that through these shapes, childrens' imaginations are being dictated from the beginning (Kanıpak, 2014). In this study, the frequent occurrence of drawings of apple-shaped swings and banana-shaped slides lends supportm to this view.

Taking careful note of the data in the literature on children's drawings suggesting that they show a greater preference for natural elements, the conclusions regarding the hypothesis in this case study, where the children were seen to prefer constructed elements, are significant. As Cronin-Jones pointed out in 2005, children can only picture what they are aware of (Cronin-Jones, 2005), and this can be considered a reason behind their preference for structural elements. In today's urban life style, children are forced to spend their time, in small play spaces squeezed in amongst buildings, and they are rarely acquainted with natural environments; this is a situation that restricts their creative and imaginative potential. The striking frequency of use of human figures in children's drawings seen in this study is similar to the high proportions of such figures found by Sali et al. (2014). Boys' and girls' preferences regarding play areas and street furnishings within the built environment (water elements, seating elements, trash cans, etc.) are similar; because elements like pools and fountains provide opportunities for play and fun, they consistently appear as preferred play elements. The presence of water elements contributes to children's psychological, social, and physical development. And so, in the design of play areas, whether they have natural or built environments, water elements must be included.

Using the imagination is essential to children in every stage of their development; and play areas provide social and physical environments which contribute to developing their imaginary worlds. This study classified children's fantasized natural and built design elements within such environments; its results will therefore be significant for the generation of data in related work in the future.

\section{References}

Altman, I., \& Chemers, M. (1980). Culture and environment, environmental cognition and perception. America: Wadsworth Inc. Altman, I., \& Zube, E. H. (2012). Public places and spaces. Boston, MA, USA: Springer.

Aura, S., Horelli, L., \& Korpela, K. (1997). Ympäristöpsykologian perusteet. Porvoo: WSOY.

Barraza, L. (1999). Children's drawings about the environment. Environmental Education Research, 5(1), 49-66.

Bechtel, R. (1997). Environment and behavior: An introduction. Thousand Oaks, CA: Sage.

Blades, M. (1989). Children's ability to learn about the environment from direct experience and from spatial representations. Children's Environments Quarterly, 6(2-3), 4-14.

Brooks, M. (2009). Drawing, visualisation and young children's exploration of "big ideas". International Journal of Science Education, 31(3), 319-341.

Canter, D. (1977). The psychology of place. New York, N.Y.: St. Martin's Press.

Chang, N. (2005). Children's drawings: Science inquiry and beyond. Contemporary Issues in. Early Childhood, 6(1), 104-106.

Clements, R. (2004). An investigation of the status of outdoor play. Contemporary Issues in Early Childhood, 5(1), 68-78.

Cohen, R. (1985). The development of spatial cognition. Hillsdale, N.J.: Erlbaum Lawrence.

Collins, R. (2008). The complete guide to playground development. Canada: Rgc Design. 
Cronin-Jones, L. (2005). Using drawings to assess student perceptions of schoolyard habitats: A case study of reform-based research in the United States. Canadian Journal of Environmental Education, 10(1), 225-240.

Crook, C. (1985). Knowledge and appearance. In N. H. Freeman and M. V. Cox (Eds.), Visual order: The nature and development of pictorial representation (pp. 248-265). Cambridge: Cambridge University Press.

Dikmen, O. (2015). Integrating a child's and a designer's perspective within outdoor playground design. International European Academy of Design Conference, EAD 11th Proceedings, April 22-24.

Downs, R. M., \& Stea, D. (Eds.). (1973). Cognitive maps and spatial behavior: Process and products. In Image \& environment: Cognitive mapping and spatial behavior (pp. 8-26). Chicago: Aldine Transaction.

Erdoğan, S., Haktanir, G., Köksal-Akyol, A., \& Çakır-İlhan, A. (2004). Oyun oynamak istediğim yer: Altı yaşındaki çocukların resimleri üzerinde bir inceleme (I want to play a game in the place I want to play: A review of pictures by six-year-olds). In Proceedings of Meeting and Conference of the World Council (pp. 285-299). Istanbul: Ya Pa Broadcast Marketing Industry and Trade. Inc.

Eriksen, A. (1985). Playground design. New York: Van Nostrand Reinhold Company.

Eyck, A. V. (1959). Het verhaal van een andere gedachte (The story of another thought). Forum 7/1959, Amsterdam and Hilversum.

Fishman, L. (2001), Child's play: An empirical study of the relationship between the physical form of schoolyards and children's behavior. Retrieved from http://www.yale.edu/hixon/research/pdf/LFisman_Playgrounds.pdf

Forsyth, A., Musacchio, L., \& Fitzgerald, F. (2005). Designing small parks: A manual for addressing social and ecological concerns. Hoboken, NJ: Wiley Publications.

Fromberg, D. P., \& Bergen, D. (1998). Play from birth to twelve and beyond: Contexts, perspectives, and meanings. New York, N.Y.: Routledge Publiciation.

Hart, R. (2002). Containing children: Some lessons on planning for play from New York City. Environment and Urbanization, $14(2), 135-148$.

Kanıpak, Ö. (2014). Katil Parklar, Istanbul Art News Aralık December 2014. Retrieved from http://www.omerkanipak.com/2014/12/15/katil-parklar/

Koppitz, E. M. (1968). Psychological evaluation of children's human figure drawings. The Psychological Corporation, Harcourt Brace Jovanovich, Inc.

Jacobson, J. L. (1998). Cognitive mapping without sight: Four preliminary studies of spatial learning. Journal of Environmental Psychology, 18, 289-305.

Lang, J. (1987). Creating architectural theory: The role of the behavioral sciences in environmental design. New York, N.Y.: Van Nostrand Reinhold.

Lewis, D., \& Greene, J. (1983). Young child's drawings: Their hidden meaning. London: Hutchinson \& Co. (Publishers) Ltd.

Little, H., \& Vyver, S. (2010). Individual differences in children's risk perception and appraisals in outdoor play environments. International Journal of Early Years Education, 18, 297-313. doi: 10.1080/09669760.2010.531600

Lowenfeld, V., \& Brittain, W. L. (1987). Creative and mental growth (8th ed.). Upper Saddle River, NJ: Prentice Hall.

Luquet, G. H. (1913). Les dessins d'un enfant. Paris: Alcan.

Malchiodi, C. (1998). Understanding children's drawings. London: Jessica Kingsley.

Matthews, M. (1985). Young children's representation of the environment: A comparison of techniques. Journal of Environmental Psychology, 5(3), 261-278.

Moore, R. C., \& Wong, H. H. (1997). Natural learning: The life history of an environmental schoolyard-Creating environments for rediscovering nature's way of teaching. Berkley, CA: MIG Communications.

Omet, D., \& al-Asad, M. (2002). Designing a play environment with children at Sahab. Retrieved from http://www.csbe.org/designing-a-play-environment-with-children-in-sahab

Panula, E. Y. (2012). School children's drawings of landscape they would like to conserve and how the drawings reflect their environmental conceptions. In AARE-APERA Joint Meeting of Australian Association in Research of Teacher Education and Asia Pacific Education Research Association, Sydney, Australia.

Piaget, J. (1955). The construction of reality in the child (Vol. 82, Cook, M., Trans). New York, N.Y.: Routledge.

Piaget, J. (1969). The child's conception of the world. London: Kean Paul.

Provenzo, E. F. (1993). Complete playground book. Syracuse, N.Y.: Syracuse University Press.

Pyle, R. (2002). Eden in a vacant lot: Special places, species and kids in community of life. In P. H. Kahn and S. R. Kellert (Eds.), Children and nature: Psychological, sociocultural and evolutionary investigations (pp. 305-327). Cambridge: MIT Press. 
Robinson, H. A. (1995). The etnography of empowerment: The transformative power of classroom interaction. New York, N.Y.: Routledge.

Sali, G., Köksal-Akyol, A., \& Baran, G. (2014). An analysis of pre-school children's perception of schoolyard through their drawings. In The 5th World Conference on Educational Sciences (WCES), Rome, Italy, 5-8 February.

Scarlett, W. G. (2005). Children's play. Thousand Oaks, CA: Sage Publication.

Schirrmacher, R. (2002). Art and creative development for young children. Albany, NY : Delmar Thomson Learning.

Sluss, D. J. (2014). Supporting play in early childhood: Environment, curriculum, assessment. Wadsworth Publishing

Solomon, S. G. (2005). American playgrounds: Revitalizing community space. Hanover: University Press of New England.

Strommen, E. (1995). Lions and tigers and bears, oh my! Children's conceptions of forests and their inhabitants. Journal of Research in Science Teaching, 32(7), 683-698.

Tamoutsei, N., \& Polyzou, E. (2010). Using drawing to assess children's perceptions of schoolyard environment: A case study of a primary school in Drama, Greece. In World Scientific and Engineering Academy and Society (WSEAS) Stevens Point, Wisconsin, USA.

Tovey, H. (2007). Playing outdoors: Spaces and places, risk and challenge. Maidenhead, UK: Open University Press.

Tuan, Y. (1977). Space and place. United States of America: University of Minnesota Press.

Van-Summers, P. (1984). Drawing and cognition. Cambridge: Cambridge University Press.

White, R., \& Stoecklin, V. (1998). Children's outdoor play \& learning environments: Returning to nature. Retrieved from http://www.whitehutchinson.com/children/articles/outdoor.shtml

Yavuzer, H. (1992). Resimleriyle çocuk. İstanbul: Remzi Kitabevi AŞ.

Yeager, A. M. (2012). Urban children's perceptions of the physical environment sarah lawrence college. ProQuest Dissertations Publishing.

Y1lmaz, S., Düzenli, T., \& Özkan, D. G. (2017). Affordances primary school gardens provide to children with 6-7 years old. Journal of the International Scientific Researches/Uluslararası Bilimsel Araştırmalar Dergisi (IBAD), 2, 130-141. 